\title{
Investor's Reaction Towards Corporate Action and Financial Performance in Asia Financial Industry
}

\author{
Juniarti Juniarti ${ }^{1}$ Marcella Stevi Angelica ${ }^{1}$ Elizabeth Fiona Cahyadi ${ }^{1, *}$
}

\author{
${ }^{1}$ Department of Business Accounting, Petra Christian University, Surabaya, Indonesia \\ *Corresponding author. Email: d12180062@john.petra.ac.id
}

\begin{abstract}
The primary objective of this study is to determine which investors value more between corporate action and financial performance in the Asia financial industry. We examine from the 486 firms that are suitable with the criteria we have. There are a total of 83 firms that made corporate action during the period 2015-2020 in Asia. We employ the event study methodology to explore the relationship of corporate action and financial performance with investor reaction. We use eleven and five days event window in our analysis. Our findings indicate that investors react positively to both corporate action and financial performance in both event windows. Further, we found corporate action has a stronger value to investors in eleven-days event window. As for financial performance, the results show that investors react more significantly to cash basis than to accrual basis.
\end{abstract}

Keywords: Corporate action, Financial industry, Financial performance, Investor reaction.

\section{INTRODUCTION}

This paper aims to analyse whether investors value financial performance or firm's corporate actions more. Investors rely heavily on financial performance to analyse the firms' performance and make predictions about its future outcomes [1]. Several research have looked into the impact of financial performance on market reaction in the past [2], [3]. However, as financial performance only reveals the firms' past and current performance, it is insubstantial for investors to make an investment decision based on past. [4], [5] find a decline in the valuation of financial performance. [6] defines value relevance as the usefulness of accounting information and the ability of financial information to influence stock prices. With information asymmetries surrounding in almost all financial transactions [4], the value relevance of financial performance is put in question since it will hinder its utility to help investors make a rational investment decision [7].

Corporate managers are faced with three decisions which include capital expenditure decision, dividend decision, and financing decision [8]. In response to the declining value relevance of financial performance, investors have shifted their attention to the corporate capital expenditure decisions to support their investment decisions. Today's stock price not only reflects the firm's current financial performance but also reveals investor's expectation on future operating performance [9]. Therefore, stock price reactions to corporate actions represent investors' evaluation of the firm's capital expenditure decisions [10]. The investment decision which a firm makes today will greatly affect market reaction in determining the firm's future success [11]. By doing merger and acquisitions, firms can bring strategic assets to acquiring firms that can lead to positive return [12]. [13] also found that the average abnormal return becomes significantly positive prior to M\&As announcement. This implies that investors value corporate action as it shows the firms' future prospects [14], [15]. When investors react in a positive manner, they will "award" the firm as the stock price goes up. Accordingly, it is apparent that investors require more than just numbers in order to make sound and rational investment decisions [16]. As corporate action give investors a greater look toward the firm's future performance, it is expected that it could support investors in making effective investment decisions [17].

Much prior literatures mainly focused on the value relevance of either financial performance [1], [18], or corporate action [13], [19], [20] in making investment decisions individually. However, study investigating which do investors value more between the two remains unclear. Thus, this study makes several important contributions. First, this study extends the current literature by comparing the value of financial 
performance and corporate action to investors, responding to the decline of value relevance in financial performance [4], [5]. Given the importance of the firms' corporate action to make investment decisions, a study on whether investors value financial performance or corporate action more is clearly needed. Moreover, these researches were mostly conducted across multiple industries [21] which is considerably weak as each industry has different characteristics [22]. Characteristics, expectation, and concern from investors differ in each industry [23]. Different investors will generate different financial returns in different industries. Therefore, we argue that research findings of a multisector industry cannot be generalized to one specific industry and vice versa [24].

In response to our argument, this study is conducted in the banking industry, which has done many mergers and acquisitions for the past three decades [25]. In Indonesia, a few small banks have made quite a name for themselves, such as PT Bank Jago Tbk (ARTO) recent investment by Gojek. During the investment announcement, ARTO's stock price increased up to $25,81 \%$ and inclined as much as $291,96 \%$ in the last 6 months prior to announcement. The significant increase in ARTO stock price indicates that the market perceives the firms made a good investment. Following ARTO, other bank that receive the same positive market reaction are the merger of 3 state-owned bank (PT BRI Syariah Tbk, PT Bank Negara Indonesia Syariah, dan PT Bank Mandiri Syariah) which put BRIS in the top 10 shares with the biggest capitalization in Indonesia market. [26] found the market is able to distinguish between good and poor investment prospects.

We especially would like to conduct this study in Asia, which plays a big role in the growth of the global banking sector [27] where more than 40 of the world's 100 largest banks by assets are Asian banks [28]. In recent years Asia has been delivering nothing but promising growth and innovations in the financial industries. It is also interesting to study this topic since many Asian banks today are focused on expanding their market reach through partnerships and M\&A. Accordingly, how investors react and whether they value this kind of information more than the financial performance would offer a new implication for both investors and management especially in the financial industry [28].

The remaining sections of this paper are organized as follows. Section 2 discusses the related literature and hypotheses development. In section 3 we present the research methods and data that we used. Section 4 discusses the analysis and the results. Lastly, conclusions and limitations are discussed in Section 5.

\section{LITERATURE REVIEW \& HYPOTHESIS DEVELOPMENT}

\subsection{Corporate Action}

Corporate action is an event conducted by firms to improve their performance and impact their stakeholders [15], [29]. When there is news involving corporate action, the firm's stock price tends to increase. Therefore, corporate action is a useful information for investors as it has a great potential to influence the firm's stock price [30]. There are some types of corporate actions, however this research only uses M\&A and new investment done by the banking industry for the past 5 years.

Mergers and acquisitions (M\&A) are a strategic move made by a firm that can signal growth opportunities [31] as M\&A can create value and be seen as the firm's overall performance [32]. [33] also believed that by doing corporate action, especially mergers and acquisition, the firm can offer some good news to investors and maximize its value for stakeholders [34]. According to S\&P Global Market Intelligence data, the financial industry's M\&A deals in Asia-Pacific tripled to 255 in 2020, from 76 in 2019. The increase in the number of M\&A deals shows that by doing merger and acquisition, Asian banks could enable effective operation [35].

Aside from M\&A, many financial institutions also do corporate action by making investments in the same or different industry. By purchasing others' stake, both target and acquirer's stock price increased. [8] also believed that markets react positively to the investment announcements. By making investment, it shows the firm's potential ability to generate income [36].

\subsection{Financial Performance}

Financial performance is a measure of success that reflects the ability of a firm to produce returns [37]. A good financial performance can reward the shareholders for their investment [38]. Therefore, investors use the information from financial performance to determine equity investments [39].

We use cash flow statements to measure financial performance. Cash flow statement shows all the monetary impact from the firm's activities [40]. This study specifically uses CFO and CFI as a measure. CFO reflects the cash generated from the daily operations [41]. $\mathrm{CFO}$ can predict the future earnings and cash flow which is useful for investors in valuing the bank's equity. Higher CFO indicates the firm is doing better as the firm's current cash flow is sufficient to satisfy funding needs [42]. While CFI provides details on cash going in and out that comes from non-current assets which is expected to develop growth and produce profit in the future [43]. CFI shows how a firm allocates its cash for the long term. A negative CFI indicates the firm's poor 
performance. However, that is not always the case as the firms need to invest on non-current assets such as plant, property, and equipment to grow [44].

Besides the cash flow statement, this study also uses Return on Assets (ROA) to measure financial performance. ROA helps to determine a firm's ability to generate profit as it indicates how much net income can be generated from assets [45]. The higher the ROA, the more profitable the bank is in utilizing its fund [46]. Last, financial performance is also measured by Earnings Per Share (EPS) which is considered to be an important ratio for making investment decision as EPS shows the firm's financial health [47]. The higher the EPS, the firm's share price will rise and increase the firm's value [48].

\subsection{Efficient Market Hypothesis}

The Efficient Market Hypothesis suggests that share price need to fully reflect all available information to the capital market. [47] classifies market efficiency into three forms: weak, semi-strong and strong form. Market is considered a weak form when historic market data and past prices are fully reflected in share prices but are unable to predict future prices. When all publicly available information is fully reflected in the share price, the market is a semi-strong form. Finally, the market will be considered as strong form when all public and private information is fully reflected in the share price.

As semi-strong form of market efficiency hypothesis suggests, share prices fully incorporate all publicly available information. Financial performance of the company is a part of public information. Therefore, prior to the disclosure of financial performance, investors create expectations and speculations. The share prices will increase if the announcement exceeds investor's expectation and decrease if it falls below the expectation of investors. It is required for the announcements made by the company, whether good or bad, that they should be fully reflected in the share price after they are made public [49].

\subsection{Investor Reaction}

Investor reaction represents the capital market's response to the firm's performance over a period [49]. As the capital market is subject to uncertainty, investors must make assumptions about how the market will respond to the firm's course of action and make decisions whether to sell or buy their stocks [50]. Investor reaction will affect the movement in the stock's price.

Investor reaction is highly related to new information that the firms disclose publicly. Many studies investigated investor reaction to new information be it financial or non-financial. For example, [49], [51] study the investor reaction to financial performance such as earnings announcements. Some others study the reaction of investors towards the firm's action namely merger \& acquisition [20], [52], dividend announcements [53], and capital expenditures [54], [55]. Positive reaction from investor would result in an increase in the stock price while a negative reaction would cause a decrease in the stock price.

We measure investor's reaction using the cumulative abnormal returns (CAR). Returns are considered abnormal when the returns generated by the company is higher than the market average. The abnormal return captures investor reaction towards the specific information that the firms disclose. In accordance, [56] found that the importance of M\&A transactions can be acquired by examining the price changes during the period in which M\&A occurs. Many prior studies also use CAR to measure investor's reaction [57]. Following [58], we use the modified market model which defines abnormal returns (AR) for any day as the difference between the firms return and the market return.

A positive and significant CAR around the announcement will cause an increase in market demand for the relevant stock which will usually be followed by an increase in the number of shares traded [31]. Accordingly, it can be said that investors react positively when CAR is positive and vice versa.

\subsection{Signalling Theory}

Signalling theory's basis says that it has to do with minimizing information asymmetry between two parties, since it is based on the idea that information is not equally available to all parties at the same time. [59]. The three main elements include signallers, receivers, and the signal itself. [60] proposed that signallers are insiders who has greater inside information not available to outsiders. Insiders have the advantage and may intentionally communicate only positive information to investors. Receivers are outside investors who lack information but would like to receive this information. Outsiders would attempt to distinguish reliable information from the unreliable ones to make investment decision-making [61]. Due to information asymmetry, outsiders cannot obtain an adequate amount of information to make investment judgement. Therefore, signalling theory suggests that investors may need to rely on other information to make decision.

This study uses signaling theory to assess how investors might react to business action in the stock market by purchasing and selling shares. The firm's announcement of M\&A and new investment serves as a signal to investors and can affect their decisions. [12]. If the announcement is received by investors as a favourable opportunity in the future, this should reflect on the stock market by increasing the stock price. While, if the announcement is interpreted negatively by investors, the stock price would decline. 


\subsection{Hypothesis Development}

Investors use publicly available financial data to forecast a company's success in the future. As financial performance contains information content that shows the association between stock price return and movement, it will be used by investors to influence their judgement. This will lead investors to make buy or sell decisions. Share price completely reflects all publicly accessible information, which is consistent with the semi-strong version of efficient market theory. Investors have prior probabilities of future firm performance, and it will change as firms disclose new information [51]. Investors' response to financial performance has been widely studied. The study of [2] concluded that investors react positively to GN firms (actual > expected) and negatively to BN firms (actual < expected). [62] also found similar results. In accordance, [63] found significant abnormal price reactions to earnings announcements. This study will explore investor reaction to financial performance using cash basis (CFO, CFI) and accrual basis (ROA, EPS). We use both, because by only relying on the profit and financial position that is prepared based on accrual basis without relying on the cash flow can lead to a wrong investment decision [40].

Financial information is an important factor used by investors to appraise the value of stock prices [12]. However, making investment decisions based on financial information alone is not enough since it only discloses the historical and current performance of the company [1]. Second, [4], [5] find a decline in the value relevance of financial information. Even under semistrong market efficiency, share prices reflect only public information while information about complex organizational events is not publicly available [64].

Beside financial information, corporate action often leads to price changes in the firm's stock. In contrast with efficient market hypothesis, signalling theory assumes that information is not equally available to all parties [59]. Therefore, firms decide to use corporate action as a signal sent to investors. Consistent with the result from [50], there is a positive market reaction to corporate action whereas the negative stock price reaction disappears when the firm does corporate action. [12] reports that the announcement of corporate action is often perceived as a strong signal to the market indicating the firms have the potential to grow. In M\&A situations, [65] find that Indian and Chinese acquiring firms can benefit from cross-border M\&As. [55] found that investors' reaction to the firm's investment depends on the quality of the firm's investment opportunities. Similarly, several studies also concluded that firms with valuable future investment opportunities will have positive market reactions [25]. Higher CAR indicates positive investor reaction. In accordance with our argument, the announcements of firms' corporate action are likely to be responded stronger by stock market investors. The above discussions lead to the following hypothesis:

$\mathrm{H}_{1}$ : Investors will react more positively to corporate action than financial performance

\section{METHOD}

\subsection{Model of Analysis}

This study's model included numerous control variables that were examined at the same time. The control variables consist of external firm-specific characteristics, namely, market capitalization, growth, and level of competitiveness. Market capitalization is an important indicator of the firm's share value [66] as it explains the expected return on stocks [67] and determines the firm's size. Therefore, market capitalization gives investors an insight about the firm's future performance and helps them make decisions [68].

Growth indicates the firm's ability to grow and has a significant positive impact on the firm value. Growth is also used by investors to consider whether to invest or not in the firm [69]. [55] found that growth opportunities influence the market reaction for firms announcing diversification investment announcements.

Level of competitiveness explains the competition level among firms in the same industry. More intensive competition implies that an industry has more firms with less market share and thus a smaller index [19]. Level of competitiveness is measured using Herfindahl Index (HHI) where higher HHI implies high industry concentration and low competition, and lower HHI implies less industry concentration and more competition.

The research model of this study is as follows:

$C A R_{i t}=\beta_{0}+\beta_{1} C O R_{i t-1} \beta_{2} C_{F O} O_{i t-1}+\beta_{3} C F I_{i t-1}+$ $\beta_{4} R O A_{i t-1}+\beta_{5} E P S_{i t-1}+\beta_{6} C A P_{i t-1}+\beta_{7} G R O_{i t-1}+$ $\beta_{8} C O M_{i t-1}+\varepsilon_{i t-1}$

\subsubsection{Variables Operationalization}

Dependent Variable:

Cumulative Abnormal Return (CAR) is the dependent variable. Following [52], we calculate CAR by first estimating the normal return $\left(\mathrm{R}_{\mathrm{it}}\right)$ of stock $\mathrm{i}$. The estimation period used in this study is 120 days, measured from 125 days to 5 days before the publication of the financial statements from each year. Individual firm return $\left(\mathrm{R}_{\mathrm{it}}\right)$ can be calculated with the following formula:

$R_{i t}=\frac{P_{i t}-P_{i t-1}}{P_{i t-1}}$

where:

$\mathrm{P}_{\mathrm{it}} \quad$ : closed stock price of company i for period $t$ 
$\mathrm{P}_{\mathrm{it}-1}$ : closed stock price of company $\mathrm{i}$ for period $\mathrm{t}-1$

Before calculating the expected return, the market return $\left(\mathrm{R}_{\mathrm{mt}}\right)$ is calculated using the following formula:

$R_{m t}=\frac{P_{m t}-P_{m t-1}}{P_{m t-1}}$

where:

$\mathrm{P}_{\mathrm{mt}}$ : closed stock price of the market for period $t$

$\mathrm{P}_{\mathrm{m} t-1}$ : closed stock price of the market for period $\mathrm{t}-1$

Using the value from Equation (2) and Equation (3), expected return $\left(E\left(R_{i t}\right)\right)$ can be measured with:

$E\left(R_{i t}\right)=\alpha+\beta \times R_{m t}$

$\alpha$ and $\beta$ are the parameters of the regression equation, where $\alpha$ is the intercept and $\beta$ is the slope that measures the stock's sensitivity with the market [70].

From Equation (2) and Equation (4), abnormal return can be calculated using the following formula [71]:

$A R_{i t}=R_{i t}-E\left(R_{i t}\right)$

Lastly, cumulative abnormal return (CAR) is calculated as the sum of daily abnormal returns during the time window $(-5,0,+5)$ and $(-2,0,+2)$

$C A R_{i}=\sum_{+t}^{-t} A R_{i t}$

Independent Variables:

- Corporate action is measured using a dummy variable that is equal to one if the firm made a corporate action deal in the past 5 years, zero otherwise.

- Financial performance in this study is measured using 4 financial ratios (CFO, CFI, ROA, EPS)

- CFO can be calculated by adding net income, noncash expense, and changes in working capital [41]. CFO in this study is divided by total assets.

- CFI can be calculated by adding sales and subtracting purchases from long-term assets, other businesses, and marketable securities [43]. CFI in this study is also divided by total assets.

- ROA is measured by dividing net income by total average assets [45].

- EPS is the firm's net income divided by the number of shares outstanding [72].

Control Variables:

- Market capitalization (CAP) can be calculated by multiplying the share price by the number of shares outstanding [68]. This study uses the logarithm of market capitalization.

- Growth (GRO) is quantified using the sales growth [73]. We calculated the growth rate using the following formula:

Growth $=\frac{s_{t-} S_{t-1}}{S_{t-1}}$
- Level of Competitiveness (COM). We use Herfindahl Index (HHI) to capture the level of competitiveness by the following formula [74].

$H H I=\sum$ market share $_{i}^{2}$

The HHI is calculated based on the sub-sectors of the industry.

\subsection{Research Sample}

These research results are expected to be generalized to firms in the financial services sector throughout Asia. Samples are selected according to the following criteria: (1) Firms available in 6 concurrent years (2015-2020); (2) Firm's financial statements are available from 20162020 to determine the abnormal returns each year; (3) CFO, CFI, ROA, EPS data are available for 6 years (2015-2020)

While samples used for financial services in Asia that do corporate action are selected according to the following criteria: Companies have completed the M\&A/new investment transactions in 2015-2021

Next, in order to compute abnormal returns, we collect data on daily stock returns and daily market returns from Yahoo Finance and Investing.

\section{RESULTS \& DISCUSSION}

Data were collected from Bloomberg Terminal and there were a total of 2791 financial institutions in Asia. Based on the above criteria, the number of firms included in the sample amounted to 486 firms. A total of 83 firms made a corporate action deal during the period 20152020. Table 1 shows the sub-sectors in the financial industry used in this study.

Table 1. Sample per sub-sectors in Asia financial industry

\begin{tabular}{|c|l|c|c|}
\hline No. & Sub-sector in financial industry & Total & $(\%)$ \\
\hline 1 & Asset Management & 45 & $9.26 \%$ \\
\hline 2 & Banks & 3 & $0.62 \%$ \\
\hline 3 & Banks - Diversified & 7 & $1.45 \%$ \\
\hline 4 & Banks - Regional & 195 & $40.12 \%$ \\
\hline 5 & Capital Markets & 98 & $20.16 \%$ \\
\hline 6 & Credit Services & 49 & $10.08 \%$ \\
\hline 7 & Financial Conglomerates & 13 & $2.67 \%$ \\
\hline 8 & Insurance - Life & 24 & $4.95 \%$ \\
\hline 9 & Insurance - Property \& Casualty & 25 & $5.14 \%$ \\
\hline 10 & Investment Services & 16 & $3.29 \%$ \\
\hline 11 & Misc. Financial Services & 6 & $1.23 \%$ \\
\hline 12 & Money Center Banks & 5 & $1.03 \%$ \\
\hline
\end{tabular}


Table 2. Descriptive statistics $(\mathrm{N}=1858)$

\begin{tabular}{|l|l|r|r|r|r|r|}
\hline No. & Variable & Mean & Median & Max & \multicolumn{1}{c|}{ Min } & Std dev \\
\hline \multirow{3}{*}{1} & $\begin{array}{l}\text { CAR } \\
(-5,0,+5)\end{array}$ & -0.0101 & -0.0042 & 0.181 & -0.3914 & 0.0531 \\
\cline { 2 - 7 } & $\begin{array}{l}\text { CAR } \\
(-2,0,+2)\end{array}$ & -0.0088 & -0.0032 & 0.1912 & -0.4955 & 0.0443 \\
\hline 2 & COR & 0.5 & 0 & 1 & 0 & 0.215 \\
\hline 3 & CFO & 0.0026 & 0.0079 & 2.5831 & -4.5205 & 0.1560 \\
\hline 4 & CFI & 0.0384 & 0.0222 & 3.0857 & -0.9413 & 0.1182 \\
\hline 5 & ROA & 0.8367 & 0.93 & 39.3307 & -157.17 & 7.5482 \\
\hline 6 & EPS & 232.279 & 3.66 & 14467 & -1460 & 969.899 \\
\hline 7 & CAP & 10.7956 & 10.8062 & 14.916 & 7.7087 & 1.3016 \\
\hline 8 & GRO & 0.3098 & 0.055 & 142.038 & -80.8746 & 5.3905 \\
\hline 9 & COM & 0.1709 & 0.1205 & 0.9993 & 0.0708 & 0.1509 \\
\hline
\end{tabular}

Table 3. Group Statistics

\begin{tabular}{|c|c|c|c|c|c|}
\hline & COR & Mean & Std Dev & t stat & Sig \\
\hline \multirow{2}{*}{$\begin{array}{l}\text { CAR } \\
(-5,0,+5)\end{array}$} & 0 & -0.0108 & 0.0535 & \multirow{2}{*}{$-2.722^{\star \star \star}$} & \multirow{2}{*}{0.007} \\
\hline & 1 & 0.0047 & 0.0421 & & \\
\hline \multirow{2}{*}{$\begin{array}{l}\text { CAR } \\
(-2,0,+2)\end{array}$} & 0 & -0.0093 & 0.0449 & \multirow{2}{*}{$-2.357^{* \star}$} & \multirow{2}{*}{0.019} \\
\hline & 1 & 0.0019 & 0.0289 & & \\
\hline
\end{tabular}

*** Correlation is significant at the 0.01 level.

** Correlation is significant at the 0.05 level.

* Correlation is significant at the 0.10 level.

This research uses 2 event windows $(-5,0,+5)$ and ($2,0,+2) \mathrm{CAR}$ as a measure for investor reaction. Table 2 shows the descriptive statistics of the variables used in this study. From the results in Table 2, we can see that between 2016-2020, the average returns using all three different measures are consistently negative. This result is consistent with [57]. Overall, the five-days event window has the highest maximum value of CAR followed eleven-days event window.

Table 3 presents the group statistics where 1 is the group of firms doing corporate action while 0 is for firms that haven't done corporate action in the last five years. The overall mean for all measures of firms with corporate action shows positive return. In contrast, for firms with no corporate action, the CARs for all event windows are negative on average. This result indicates that investors have a higher reaction to firms that have done corporate action. It is consistent with the result from [52] that when a firm does corporate action, the firm will have a higher value of return.

Before testing our hypothesis, we verify the validity of our research model using the Kolmogorov-Smirnov normality test. From the test, it shows that the data used in this study are not normally distributed since the pvalue are below 0.001, however the Central Limit Theorem (CLT) states that the sampling distribution of a large sample is approximately normal [75].
Table 4. Partial Correlation

\begin{tabular}{|c|c|c|c|c|c|c|c|}
\hline & $\begin{array}{c}\text { CAR } \\
(-5,0,+5)\end{array}$ & \begin{tabular}{|c|} 
CAR \\
$(-$ \\
$2,0,+2)$
\end{tabular} & COR & CFO & $\mathrm{CFl}$ & $\mathrm{ROA}$ & EPS \\
\hline $\begin{array}{l}\text { CAR } \\
(- \\
5,0,+5)\end{array}$ & 1 & & & & & & \\
\hline $\begin{array}{l}\text { CAR } \\
(- \\
2,0,+2)\end{array}$ & $0.546^{\star \star}$ & 1 & & & & & \\
\hline COR & $0.057^{\star}$ & $0.046^{\star}$ & 1 & & & & \\
\hline CFO & 0.042 & $0.060^{*}$ & -0.014 & 1 & & & \\
\hline $\mathrm{CFI}$ & 0.022 & 0.006 & -0.007 & $-0.299 * *$ & 1 & & \\
\hline ROA & $0.124^{* \star}$ & $\begin{array}{r}0.113^{*} \\
* \\
\end{array}$ & \begin{tabular}{r|}
- \\
$0.049 *$ \\
\end{tabular} & $0.185^{\star *}$ & 0.034 & 1 & \\
\hline EPS & 0.008 & -0.011 & $0.050 *$ & -0.035 & 0.019 & -0.019 & 1 \\
\hline
\end{tabular}

Next, we continue to test the correlation between each variable using the partial correlation (shown on Table 4). The result shows that $(-5,0,+5)$ CAR correlates with COR and ROA, $(-2,0,+2)$ CAR correlates with COR, CFO, and ROA. And last, we test the multicollinearity test among variables. The VIF values are all below 10, suggesting there is no multicollinearity in the model.

\subsection{Hypothesis Testing}

The main purpose of this study is to seek evidence on which do investors value more, corporate action or financial performance. We present the comparative analysis for investor reaction towards corporate action and financial performance in Table 5.

We first tested the relationship between investor reaction and corporate action as well as financial performance using CAR $(-5,0,+5)$ measurement. As seen in Panel A of Table 5, the association between investor reaction and corporate action is found to be positive and significant at $1 \%$ level. We also found that the financial performance proxied by ROA has a positive and significant association with investor reaction. Firms with positive ROA will attract investors as it shows the firm's ability to generate profit from its assets [46]. The CFO, CFI, and EPS are positive but show no significant relationship with investor reaction. The coefficient of corporate action shows a higher value than ROA $(1.5 \%$ > $0.1 \%$ ). This indicates that in the eleven-days event window, investor reaction to corporate action is stronger than financial performance. 
Table 5 Panel A. CAR $(-5,0,+5)$

\begin{tabular}{|c|c|c|c|}
\hline \multirow[b]{2}{*}{ Variable } & \multicolumn{3}{|c|}{ Model 1} \\
\hline & Coefficient & t stat & Sig \\
\hline COR & 0.015 & $2.672^{* * *}$ & 0.008 \\
\hline CFO & 0.013 & 1.14 & 0.255 \\
\hline CFI & 0.016 & 1.099 & 0.272 \\
\hline ROA & 0.001 & $5.048 * \star \star$ & $<0.001$ \\
\hline EPS & 0.000000443 & 0.341 & 0.733 \\
\hline CAP & 0.003 & $2.679 * * *$ & 0.007 \\
\hline COM & -0.012 & -1.428 & 0.153 \\
\hline GRO & -0.001 & $-3.546^{* * *}$ & $<0.001$ \\
\hline Constant & -0.038 & $-3.481^{* * *}$ & $<0.001$ \\
\hline $\mathrm{R}^{2}$ & 0.034 & & \\
\hline Adjusted $\mathrm{R}^{2}$ & 0.029 & & \\
\hline $\mathrm{F}$ & & $7.777^{\star * \star}$ & $<0.001 b$ \\
\hline
\end{tabular}

Table 6 Panel B. CAR $(-2,0,+2)$

\begin{tabular}{|c|c|c|c|}
\hline & \multicolumn{3}{|c|}{ Model 2} \\
\hline Variable & Coefficient & t stat & Sig \\
\hline COR & 0.011 & $2.257^{\star \star}$ & 0.024 \\
\hline CFO & 0.017 & $1.807^{\star}$ & 0.071 \\
\hline $\mathrm{CFI}$ & 0.008 & 0.684 & 0.494 \\
\hline ROA & 0.001 & $4.447^{\star \star \star}$ & $<0.001$ \\
\hline EPS & -0.0000004735 & -0.431 & 0.666 \\
\hline CAP & 0.003 & $2.966^{\star * \star}$ & 0.003 \\
\hline COM & -0.023 & $-3.365^{\star}$ & $<0.001$ \\
\hline GRO & 0 & -1.572 & 0.116 \\
\hline Constant & -0.033 & $-3.535^{\star * \star}$ & $<0.001$ \\
\hline$R^{2}$ & 0.032 & & \\
\hline Adjusted $\mathrm{R}^{2}$ & 0.027 & & \\
\hline$F$ & & $7.335^{\star \star \star}$ & $<0.001 b$ \\
\hline
\end{tabular}

Meanwhile Panel B of Table 6 presents cumulative abnormal return for the window period of $(-2,0,+2)$. The result for corporate action shows a positive CAR amounting to $1.1 \%$ and is statistically significant at $5 \%$ level. The positive relationship shows that as firms do corporate action, the higher the investor reaction will be. It suggests that the market perceives corporate action as good news which is consistent with the results from [50]. Panel B also shows that CFO and ROA have a positive and significant relationship with investor reaction at $1.7 \%$ and $0.1 \%$ consecutively. While CFI and EPS show no significant relationship with investor reaction. This finding implies that financial performance is being responded stronger than corporate action, and that the cash basis is seen to be more valuable compared to accrual basis.

The market capitalizations for all models are found to be positive and significant in affecting investor reaction. As market capitalization indicates the firm's share value, it gives investors an insight about future performance, thus affecting the market reaction positively [76].

In the eleven-days event window, we found that corporate action has the highest coefficient, while in the five days event window, CFO has the highest coefficient value. But since the adjusted $\mathrm{R}^{2}$ for Model 1 shows the highest value, corporate action and financial performance explains the change of investor reaction better in the eleven-days event window. The F-ratios for all models are all above 2 , showing that the models used in this study are fit.

\subsection{Discussion}

This study investigates investor reaction toward corporate action and financial performance. As the market is full of uncertainty, investors need information to influence their judgement. In this study, corporate action and financial performance serves as information that firms publicly provide. Our study complements prior literatures by comparing which one do investors value more between corporate action and financial performance in terms of making investment decisions.

Our results found that corporate action done by the firm contains a positive information signal in the eleven and five-days event window. This finding is consistent with studies from [20] who found that in the eleven-days event windows and [74] in five-days event windows that corporate action has a significant relationship with investor reaction. According to signalling theory, information is not publicly available therefore firms need to send a signal to influence investor judgement. In accordance with [19] and [26]'s findings that the market interprets corporate action as signals for the future prospect of the firm. Investors perceive firms that have done corporate action have potential to grow. Therefore, investors place a premium on firms with corporate action and increase the stock prices.

Second, our finding is also consistent with previous studies in which financial information affects investor reaction positively and significantly [18].This finding indicates that investors relied on this information to make investment decisions. Positive investor reaction to financial performance is in accordance with efficient market hypothesis in which all publicly available information is fully reflected in the stock prices [49]. Based on 2 event windows that we use in this study, we find that ROA has a positive and significant value which is consistent with [77]. We also find CFO in five days event window positively affects investor reaction. As 
CFO helps investors to predict future earnings, a high level of CFO is associated with positive and significant CAR. This finding is consistent with previous literatures [42]. Further, our finding also suggest that cash basis has a greater information value to investors compared to accrual basis. Cash flow information is useful in helping investors assess the ability of the firms to generate cash and compare the present value of future cash flow of different firms. In accordance, [78] identifies that cash basis has a superior association in influencing investor judgement as cash basis has the ability to forecast the firm's future liquidity [79]. A greater value of cash basis indicates the firm ability to generate dividend.

Finally, our findings found that based on the elevendays event window, investors value corporate action better than financial performance. Meanwhile, on the five-days event window, financial performance has greater value to investors. From the adjusted $\mathrm{R}^{2}$ we found that Model 1 has the highest adjusted $\mathrm{R}^{2}$ value compared to model 2. We can conclude that Model 1 which is the eleven-days event window is the better event window to measure the association between investor reaction to corporate action and financial performance. Model 1 shows that COR coefficient is higher than ROA as the financial performance proxy, indicating that investors react more significantly to corporate action. Therefore, hypothesis 1 is supported.

This study has some implications for corporate managers. Corporate managers can make use of this finding and consider making a corporate action decision. This decision could help influence positive reaction from investors, therefore they will reward the firm as there is an increase in the stock prices. Managers could also focus on improving the firms cash flow, specifically cash flow from operations to maximize investor reaction and increase stock prices.

\section{CONCLUSION}

This study shows that corporate action and financial performance are positively and significantly associated with investors' reaction in $(-5,0,+5)$ and $(-2,0,+2)$ event windows. First, in our fittest model which is the elevendays event window, investors react to corporate action stronger compared to financial performance. In the fivedays event window, we found that corporate action and financial performance is significant, however financial performance is more presiding. Further, we found that in the context of financial performance, information from cash basis is more valuable than accrual basis. Overall, we can conclude that corporate action made by the firm is considered as a positive signal that influences investors' decisions. Nevertheless, companies and managers should focus on both corporate action and financial performance to positively influence investors' perception in buying their stocks.

This study is subject to certain limitations. The researchers only use M\&A and new investment to define corporate action. Future study could explore more corporate action types in the study to explain the relationship between corporate action and investor reaction. Also, this study is limited to the Asia financial industry while every industry has its own characteristics.

\section{AUTHORS' CONTRIBUTIONS}

Author 1 conceived and designed the study. Author 2 and author 3 collected and analysed the data. All authors contributed to writing the paper. The final manuscript is read and approved by all authors.

\section{ACKNOWLEDGMENTS}

Author 2 and author 3 would like to thank Dr. Dra. Juniarti, M.Si., Ak. and Petra Christian University for the continuous support and encouragement.

\section{REFERENCES}

[1] M. Naveed, S. Ali, K. Iqbal, and M. K. Sohail, "Role of financial and non-financial information in determining individual investor investment decision: a signaling perspective," South Asian J. Bus. Stud., vol. 9, no. 2, pp. 261278, May 2020, doi: 10.1108/SAJBS-09-20190168 .

[2] R. Ball and P. Brown, "An Empirical Evaluation of Accounting Income Numbers," J. Account. Res., vol. 6, no. 2, p. 159, 1968, doi: $10.2307 / 2490232$.

[3] D. Tarmidi, G. N. Fitria, and Z. Ahmad, "Financial Performance and Audit Quality: Comparative Study of Investor Reaction," Sch. Bull., vol. 05, no. 12, pp. 828-833, Dec. 2019, doi: 10.36348/sb.2019.v05i12.019.

[4] E. Blankespoor, E. Dehaan, J. Wertz, and C. Zhu, "Why Do Individual Investors Disregard Accounting Information? The Roles of Information Awareness and Acquisition Costs," J. Account. Res., vol. 57, no. 1, pp. 5384, Mar. 2019, doi: 10.1111/1475679X.12248.

[5] D. Givoly, C. Hayn, and S. Katz, "The changing relevance of accounting information to debt holders over time," Rev. Account. Stud., vol. 22, no. 1, pp. 64-108, Mar. 2017, doi: 10.1007/s11142-016-9374-y.

[6] J. Francis and K. Schipper, "Have Financial Statements Lost Their Relevance?," J. Account. Res., vol. 37, no. 2, p. 319, 1999, doi: 


\section{$10.2307 / 2491412$.}

[7] X. Cui and T. Shibata, "Investment strategies, reversibility, and asymmetric information," Eur. J. Oper. Res., vol. 263, no. 3, pp. 11091122, Dec. 2017, doi: 10.1016/j.ejor.2017.06.032.

[8] K. H. Chung, P. Wright, and C. Charoenwong, "Investment opportunities and market reaction to capital expenditure decisions," J. Bank. Financ., vol. 22, no. 1, pp. 41-60, Jan. 1998, doi: 10.1016/S0378-4266(97)00021-6.

[9] R. A. Brealey, S. C. Myers, and F. Allen, Principles of Corporate Action, 13th ed. McGraw-Hill Education, 2020.

[10] J. R. Woolridge and C. C. Snow, "Stock market reaction to strategic investment decisions," Strateg. Manag. J., vol. 11, no. 5, pp. 353-363, Sep. 1990, doi: 10.1002/smj.4250110503.

[11] H. J. Bierman and S. Smidt, The Capital Budgeting Decision Economic Analysis of Investment Projects, 1st ed. Routledge, 2007.

[12] F. Tao, X. Liu, L. Gao, and E. Xia, "Do crossborder mergers and acquisitions increase shortterm market performance? The case of Chinese firms," Int. Bus. Rev., vol. 26, no. 1, pp. 189202, Feb. 2017, doi: 10.1016/j.ibusrev.2016.06.006.

[13] J. Feng, R. Segara, and J. Y. Yang, "Stock Price Movements and Trading Behaviors Around Merger and Acquisition Announcements: Evidence from the Korean Stock Market," SSRN Electron. J., 2018, doi: 10.2139/ssrn.3138231.

[14] A. J. Avwokeni, "On the value relevance argument," J. Financ. Report. Account., vol. 16, no. 4, pp. 660-676, Dec. 2018, doi: 10.1108/JFRA-02-2017-0012.

[15] N. Marisetty and M. S. Babu, "Impact of Corporate Action (Different Stock Split Ratios) on Stock Price in India," Int. J. Res. Econ. Soc. Sci., vol. 8, no. 1, pp. 205-213, 2018.

[16] J. Al-Ajmi, "Investors' use of corporate reports in Bahrain," Manag. Audit. J., vol. 24, no. 3, pp. 266-289, Mar. 2009, doi: 10.1108/02686900910941140.

[17] K. Kishan and E. Alfan, "Malaysian Individual Investors: What Are the Factors That Influence Their Financial Statement Usage?," Asian J.
Account. Perspect., vol. 12, no. 1, pp. 22-48, Feb. 2019, doi: 10.22452/AJAP.vol12no1.2.

[18] S. Honggowati, "Value Relevance of Financial and Non-Financial Information to Investor Decision," Glob. Bus. Financ. Rev., vol. 20, no. 2, pp. 95-104, Dec. 2015, doi: 10.17549/gbfr.2015.20.2.95.

[19] X. Lin, Y. Li, X. Wan, and J. Wei, "Market reaction to the international acquisitions by Chinese firms," Chinese Manag. Stud., vol. 14, no. 4, pp. 915-934, Apr. 2020, doi: 10.1108/CMS-11-2019-0394.

[20] L. Ning, J.-M. Kuo, R. Strange, and B. Wang, "International investors' reactions to crossborder acquisitions by emerging market multinationals," Int. Bus. Rev., vol. 23, no. 4, pp. 811-823, Aug. 2014, doi: 10.1016/j.ibusrev.2013.12.003.

[21] A. Habib, "Value relevance of alternative accounting performance measures: Australian evidence," Account. Res. J., vol. 23, no. 2, pp. 190-212, Sep. 2010, doi: 10.1108/10309611011073269.

[22] O. I. Tukel and W. O. Rom, "Analysis of the characteristics of projects in diverse industries," J. Oper. Manag., vol. 16, no. 1, pp. 43-61, Jan. 1998, doi: 10.1016/S02726963(97)00016-8.

[23] M. Feng, X. Wang, and J. G. Kreuze, "Corporate social responsibility and firm financial performance," Am. J. Bus., vol. 32, no. 3-4, pp. 106-133, Aug. 2017, doi: 10.1108/AJB-05-2016-0015.

[24] R. Salehzadeh, J. Khazaei Pool, and A. H. Jafari Najafabadi, "Exploring the relationship between corporate social responsibility, brand image and brand equity in Iranian banking industry," J. Islam. Account. Bus. Res., vol. 9, no. 2, pp. 106-118, Mar. 2018, doi: 10.1108/JIABR-11-2014-0041.

[25] Q. Chen and R. Vashishtha, "The effects of bank mergers on corporate information disclosure," J. Account. Econ., vol. 64, no. 1, pp. 56-77, Aug. 2017, doi: 10.1016/j.jacceco.2017.05.003.

[26] S. H. Chan, G. W. Gau, and K. Wang, "Stock Market Reaction to Capital Investment Decisions: Evidence from Business Relocations," J. Financ. Quant. Anal., vol. 30, no. 1 , p. 81, Mar. 1995, doi: 10.2307/2331254. 
[27] S. Anjum and T. Ali, "Role of Effective Training and Development Programs in Achieving High Professional Performance in Asian Banking Industry," J. Financ. Account. Manag., vol. 9, no. 2, pp. 1-10, 2018.

[28] O. Tonby et al., "The Future of Asia," 2019. .

[29] F. P. Romero, "Market Volatility in Response to Merger and Acquisition Announcements: Evidence from Selected Industries in the Philippine Market," Adv. Sci. Lett., vol. 23, no. 8, pp. 7606-7609, Aug. 2017, doi: 10.1166/asl.2017.9533.

[30] T. Okimoto, "Stock Market Predictability Using News Indexes," 2015.

[31] A. Nurwulandari, H. Hasanudin, and $M$. Melati, "MARKET REACTIONS ON CORPORATE ACTIONS IN GROWING AND NONGROWING ENERGY CONSUMING COMPANIES," Int. J. Energy Econ. Policy, vol. 11, no. 3, pp. 290-295, Apr. 2021, doi: 10.32479/ijeep.10737.

[32] P. Meyer-Doyle, S. Lee, and C. E. Helfat, "Disentangling the microfoundations of acquisition behavior and performance," Strateg. Manag. J., vol. 40, no. 11, pp. 17331756, Nov. 2019, doi: 10.1002/smj.3069.

[33] S. Shirur, "Dilemma of Corporate Action: Empirical Evidences of Bonus Issue vs. Stock Split," Vikalpa J. Decis. Makers, vol. 33, no. 3, pp. 35-48, Jul. 2008, doi: $10.1177 / 0256090920080303$.

[34] B. Al Qudaiby and M. R. Khan, "Financial Synergy in Mergers and Acquisitions in Saudi Arabia," Aestimatio, IEB Int. J. Financ., vol. 9, pp. 182-199, 2014.

[35] Y. Shirasu and H. Kawakita, "Long-term financial performance of corporate social responsibility," Glob. Financ. J., p. 100532, May 2020, doi: 10.1016/j.gfj.2020.100532.

[36] E. Lyapuntsova, I. Belozerova, I. Drozdova, and M. Berlinova, "Investment Risks in the Field of Social Entrepreneurship," MATEC Web Conf., vol. 251, p. 06019, Dec. 2018, doi: 10.1051/matecconf/201825106019.

[37] W. Salah, "The International Financial Reporting Standards and Firm Performance: A Systematic Review," Appl. Financ. Account., vol. 6, no. 2, p. 1, Jun. 2020, doi: 10.11114/afa.v6i2.4851.
[38] V. O. Ongore and G. B. Kusa, "Determinants of Financial Performance of Commercial Banks in Kenya," Int. J. Econ. Financ. Issues, Econjournals, vol. 3, no. 1, 2013.

[39] A. H. Almagtome and Z. F. Abbas, "Value Relevance of Financial Performance Measures: An Empirical Study," Int. J. Psychosoc. Rehabil., vol. 24, no. 7, 2020, doi: 10.37200/IJPR/V24I7/PR270642.

[40] M. Kamel Al Zobi and O. Hel Al-Dhaimesh, "The impact of cash flow statement components on stock volatility: Evidence from Qatar," Invest. Manag. Financ. Innov., vol. 18, no. 2, pp. 365-373, Jun. 2021, doi: 10.21511/imfi.18(2).2021.29.

[41] E. T. Nwaeze, S. S. M. Yang, and Q. J. Yin, "Accounting Information and CEO Compensation: The Role of Cash Flow from Operations in the Presence of Earnings*," Contemp. Account. Res., vol. 23, no. 1, pp. 227-265, Mar. 2006, doi: 10.1506/BUQJ8KUQ-X2TF-K7T4.

[42] C. Harris and S. Roark, "Cash flow risk and capital structure decisions," Financ. Res. Lett., vol. 29, pp. 393-397, Jun. 2019, doi: 10.1016/j.frl.2018.09.005.

[43] E. L. Black, "Which is More Value-Relevant: Earnings or Cash Flows?," SSRN Electron. J., 1998, doi: 10.2139/ssrn.118089.

[44] J. H. Hertenstein and S. M. Mckinnon, "Solving the puzzle of the cash flow statement," Bus. Horiz., vol. 40, no. 1, pp. 6976, Jan. 1997, doi: 10.1016/S00076813(97)90028-8.

[45] A. Y.-F. Ho, H.-Y. Liang, and T. Tumurbaatar, "The Impact of Corporate Social Responsibility on Financial Performance: Evidence from Commercial Banks in Mongolia," 2019, pp. 109-153.

[46] L. Wen-gang, L. Zheng-wei, and T. Li-jun, "On the Construction of Corporate Social Responsibility (CSR) Indicator System in Chinese Retailing Industry," J. Beijing Technol. Bus. Univ. (Social Sci., vol. 1, 2010.

[47] E. F. Fama, "Efficient Capital Markets: A Review of Theory and Empirical Work," J. Finance, vol. 25, no. 2, p. 383, May 1970, doi: $10.2307 / 2325486$.

[48] K. Safitri, I. M. Mertha, N. G. P. Wirawati, and A. Dewi, "The Impact of Debt to Equity Ratio, 
Price Earning Ratio, Earning per Share to the Stock Price on Banking Sectors Listed in Infobank15 Index 2014-2018," Am. J. Humanit. Soc. Sci. Res., vol. 4, no. 5, pp. 4956, 2020.

[49] A. M. Syed and I. A. Bajwa, "Earnings announcements, stock price reaction and market efficiency - the case of Saudi Arabia," Int. J. Islam. Middle East. Financ. Manag., vol. 11, no. 3, pp. 416-431, Aug. 2018, doi: 10.1108/IMEFM-02-2017-0044.

[50] L. Jianchuan, "The Stock Price Reaction to Investment News: New Evidence from Modeling Optimal Capex and Capex Guidance," 2016.

[51] M. Melgarejo, E. Montiel, and L. Sanz, "The stock market's reaction to accounting information: the cases of Chile and Peru," $J$. Account. Emerg. Econ., vol. 6, no. 3, pp. 254268, Aug. 2016, doi: 10.1108/JAEE-11-20130054 .

[52] Z. Zhang, M. A. Lyles, and C. Wu, "The stock market performance of exploration-oriented and exploitation-oriented cross-border mergers and acquisitions: Evidence from emerging market enterprises," Int. Bus. Rev., vol. 29, no. 4, p. 101707, Aug. 2020, doi: 10.1016/j.ibusrev.2020.101707.

[53] F. K. Ozo and T. G. Arun, "Stock market reaction to cash dividends: evidence from the Nigerian stock market," Manag. Financ., vol. 45, no. 3, pp. 366-380, Mar. 2019, doi: 10.1108/MF-09-2017-0351.

[54] E. Jones *, J. Danbolt, and I. Hirst, "Company investment announcements and the market value of the firm," Eur. J. Financ., vol. 10, no. 5, pp. 437-452, Oct. 2004, doi: $10.1080 / 1351847032000168696$.

[55] P. Kaur and R. Kaur, "Effects of Strategic Investment Decisions on Value of Firm: Evidence from India," Paradigm, vol. 23, no. 1, pp. 1-19, Jun. 2019, doi: $10.1177 / 0971890719835442$.

[56] A. Zaheer, E. Hernandez, and S. Banerjee, "Prior Alliances with Targets and Acquisition Performance in Knowledge-Intensive Industries," Organ. Sci., vol. 21, no. 5, pp. 1072-1091, Oct. 2010, doi: 10.1287/orsc. 1100.0528 .

[57] B. Aybar and A. Ficici, "Cross-border acquisitions and firm value: An analysis of emerging-market multinationals," J. Int. Bus. Stud., vol. 40, no. 8, pp. 1317-1338, Oct. 2009, doi: $10.1057 /$ jibs.2009.15.

[58] S. J. Brown and J. B. Warner, "Using daily stock returns," J. financ. econ., vol. 14, no. 1, pp. 3-31, Mar. 1985, doi: 10.1016/0304405X(85) $90042-X$.

[59] M. Spence, "Signaling in Retrospect and the Informational Structure of Markets," Am. Econ. Rev., vol. 92, no. 3, pp. 434-459, May 2002, doi: 10.1257/00028280260136200.

[60] M. Spence, "Job Market Signaling," $Q . J$. Econ., vol. 87, no. 3, p. 355, Aug. 1973, doi: $10.2307 / 1882010$.

[61] B. P. Miller, "The Effects of Reporting Complexity on Small and Large Investor Trading," SSRN Electron. J., 2010, doi: 10.2139/ssrn. 1473863 .

[62] W. Louhichi, "Adjustment of stock prices to earnings announcements: evidence from Euronext Paris," Rev. Account. Financ., vol. 7, no. 1, pp. 102-115, Feb. 2008, doi: 10.1108/14757700810853879.

[63] P. N. Afego, "Stock Price Response to Earnings Announcements: Evidence From the Nigerian Stock Market," J. African Bus., vol. 14, no. 3, pp. 141-149, Sep. 2013, doi: 10.1080/15228916.2013.844008.

[64] G. DeLong and R. DeYoung, "Learning by Observing: Information Spillovers in the Execution and Valuation of Commercial Bank M\&amp;As," J. Finance, vol. 62, no. 1, pp. 181-216, Feb. 2007, doi: 10.1111/j.15406261.2007.01205.x.

[65] R. R. Nicholson and J. Salaber, "The motives and performance of cross-border acquirers from emerging economies: Comparison between Chinese and Indian firms," Int. Bus. Rev., vol. 22, no. 6, pp. 963-980, Dec. 2013, doi: 10.1016/j.ibusrev.2013.02.003.

[66] A. Dias, "Market capitalization and Value-atRisk," J. Bank. Financ., vol. 37, no. 12, pp. 5248-5260, Dec. 2013, doi: 10.1016/j.jbankfin.2013.04.015.

[67] E. F. Fama and K. R. French, "The CrossSection of Expected Stock Returns," $J$. Finance, vol. 47, no. 2, pp. 427-465, Jun. 1992, doi: 10.1111/j.1540-6261.1992.tb04398.x. 
[68] M. Praveen Kumar and N. V. Manoj Kumara, "Market capitalization: Pre and post COVID19 analysis," Mater. Today Proc., vol. 37, pp. 2553-2557, 2021 , doi: 10.1016/j.matpr.2020.08.493.

[69] A. Z. Fajaria and Isnalita, "The Effect of Profitability, Liquidity, Leverage and Firm Growth of Firm Value with its Dividend Policy as a Moderating Variable," Int. J. Manag. Stud. Res., vol. 6, no. 10, pp. 55-69, 2018.

[70] G. Singh and L. Padmakumari, "Stock market reaction to inflation announcement in the Indian stock market: A sectoral analysis," Cogent Econ. Financ., vol. 8, no. 1, p. 1723827, Jan. 2020, doi: $10.1080 / 23322039.2020 .1723827$.

[71] A. C. MacKinlay, "Event Studies in Economics and Finance," J. Econ. Lit., vol. 35, no. 1, pp. 13-39, 1997.

[72] M. Sholichah, M. Jihadi, B. Widagdo, N. Mardiani, D. Nurjannah, and Y. Aulia, "The Effect of RGEC and EPS on Stock Prices: Evidence from Commercial Banks in Indonesia," J. Asian Financ. Econ. Bus., vol. 8, no. 8, pp. 67-74, 2021.

[73] S.-O. Daunfeldt, N. Elert, and D. Johansson, "The Economic Contribution of High-Growth Firms: Do Policy Implications Depend on the Choice of Growth Indicator?," J. Ind. Compet. Trade, vol. 14, no. 3, pp. 337-365, Sep. 2014, doi: 10.1007/s10842-013-0168-7.

[74] J. J. Li, L. Poppo, and K. Z. Zhou, "Do managerial ties in China always produce value? Competition, uncertainty, and domestic vs. foreign firms," Strateg. Manag. J., vol. 29, no. 4, pp. 383-400, Apr. 2008, doi: 10.1002/smj.665.

[75] C. J. Anderson, "Central Limit Theorem," in The Corsini Encyclopedia of Psychology, Hoboken, NJ, USA: John Wiley \& Sons, Inc., 2010.

[76] D. Etzion and A. Pe'er, "Mixed signals: A dynamic analysis of warranty provision in the automotive industry, 1960-2008," Strateg. Manag. J., vol. 35, no. 11, pp. 1605-1625, Nov. 2014, doi: 10.1002/smj.2178.

[77] M. Fathony, A. Khaq, and E. Endri, "The Effect of Corporate Social Responsibility and Financial Performance on Stock Returns," Int. J. Innov. Creat. Chang., vol. 13, no. 1, 2020.
[78] J. Consler, G. M. Lepak, and S. F. Havranek, "Earnings per share versus cash flow per share as predictor of dividends per share," Manag. Financ., vol. 37, no. 5, pp. 482-488, Apr. 2011, doi: 10.1108/03074351111126960.

[79] R. ROLL, E. SCHWARTZ, and A. SUBRAHMANYAM, "Liquidity and the Law of One Price: The Case of the Futures-Cash Basis," J. Finance, vol. 62, no. 5, pp. 22012234, Oct. 2007, doi: 10.1111/j.15406261.2007.01273.x. 